\title{
Climate Change Will Increase the Vector Capacity of the Aedes aegypti in South America: A Systematic
}

\section{Map}

Liliana I. Maz

Portland State University

Richard S. Lockwood

Follow this and additional works at: https://pdxscholar.library.pdx.edu/mcnair Let us know how access to this document benefits you.

\section{Recommended Citation}

Maz, Liliana I. and Lockwood, Richard S. (2021) "Climate Change Will Increase the Vector Capacity of the Aedes aegypti in South America: A Systematic Map," PSU McNair Scholars Online Journal: Vol. 15: Iss. 1, Article 1.

https://doi.org/10.15760/mcnair.2021.15.1.1 


\section{Introduction}

The mosquito Aedes aegypti (Diptera: Culicidae) is the vector of several arboviruses that significantly impact the global burden of disease, including dengue (DENV), chikungunya (CHIKV), and Zika (ZIKV). The diseases brought on by these arboviruses have garnered considerable attention in the last few decades. The incidence of the geographical spread of human disease caused by these viruses has increased dramatically within their range, in addition to occurring in new geographical locations (Kraemer et al., 2015). Notable outbreaks include the major ZIKV outbreak in the Americas in 2014 (Chang et al., 2016), the CHIKV outbreak on Réunion Island in 2005 (Borgherini et al., 2007), and a severe DENV outbreak in Rio de Janeiro in 2002 (Nogueira et al., 2005). A troubling concern is the vector's ability to adapt effectively to varying environmental conditions (Mohammed \& Chadee, 2011.) Indeed, the mosquito has evolved remarkably quickly into a competent vector. It is thought to have evolved from a zoophilic treehole ancestral mosquito named Aedes aegypti formosus in Sub-Saharan Africa (Powell \& Tabachnick, 2013; Brown et al., 2014), and was introduced into the New World with the slave trade, from which it immediately spread globally (Brown et al., 2014). As the vector is poikilothermic, it was able to respond rapidly to the changes in the environment and eventually settled into empty natural niches (Mohammed \& Chadee, 2011; Powell \& Tabachnick, 2013). In time, the Ae. aegypti's peridomestic habits and endophagic disposition established it as an opportune vector for emerging tropical diseases (Moncayo et al., 2004).

Currently affecting millions of people globally, these tropical infectious diseases are among the most critical global health concerns. Present efforts to reduce the incidence of these infectious diseases center around vector control, including larvicide application, indoor residual spraying (IRS), and mosquito surveillance (Lippi et al., 2019). Except for yellow fever (YFV), presently, there is no vaccine for the arboviruses that the Ae. aegypti mosquito transmits (Kantor, 2018), which impairs efforts to decrease the significant disease burden it imposes. As such, monitoring the current range and predicting changes in the distribution of the vector is a crucial strategy for effective disease control planning (Messina et al., 2015). While a considerable level of interest has been invested in this emerging field of research, it was not clear from an exploratory literature search whether South America is represented at the same levels as the African and Southeast Asian regions. DENV, CHIKV, and lymphatic filariasis, all transmitted by the Ae. aegypti mosquito, are classified by the World Health Organization (WHO) as neglected tropical diseases (NTD) (World Health Organization, n.d.). Although the UN did not include NTDs in the Millennium Development Goals (MDGs), they were subsequently included in the Sustainable Development Goals (SDGs) as measurable targets, with the purpose of ending epidemics (Vanderslott, 2019). In South America, the burden of disease from these arboviruses has significantly impeded economic development and represents significant opportunity costs. Therefore, it is imperative that this region not be overlooked (Franco-Paredes et al., 2007).

\subsection{Vectorial Capacity}


A limiting factor in the Ae. aegypti's geographic distribution has been its inability to tolerate temperatures below $15^{\circ} \mathrm{C}$ (Brady et al., 2013); therefore, it has predominantly settled in tropical and subtropical regions (Weaver, 2014). Recent reports predict that global temperatures will increase between $1.4-5.8^{\circ} \mathrm{C}$, and in Latin America between $1.0-4.0^{\circ} \mathrm{C}$ by 2050 (Intergovernmental Panel on Climate Change, 2007). Consequently, a growing concern is how it will impact the vectorial capacity of the mosquito. In addition to range, temperature plays a pivotal role in a variety of characteristics of the Ae. aegypti: frequency of blood meals (Scott et al., 2000); sex ratio in larvae (Mohammed \& Chadee, 2011); development duration (Farjana et al., 2011); population density (El Moustaid \& Johnson, 2019); pathogen transmission (Reinhold et al., 2018); and adult survival rate (Culbert et al., 2019). Thus, it is crucial to examine how increasing temperatures may potentially affect $A e$. aegypti's competence as a vector.

The Ae. aegypti mosquito transmits arboviruses, or "arthropod-borne viruses," which are predominantly RNA genomes that have a high rate of mutation and thus evolve rapidly. Temperature can impact the rate at which viruses replicate in the mosquito's midgut, shortening the extrinsic incubation period (EIP) and reaching the salivary glands at an accelerated rate (Winokur et al., 2020). Additionally, Ae. aegypti mosquitoes can transmit DENV, ZIKV, and CHIKV vertically; that is, infected female mosquitoes can pass the viruses on to their progeny (Alonso-Palomares et al., 2019). This ability has contributed to the maintenance of viruses during inter-epidemic periods (Lequime \& Lambrechts, 2014).

\subsection{Blood Feeding}

Given that the mode of disease transmission in the Ae. aegypti mosquito is through bloodfeeding, it is essential to understand what factors affect the frequency of blood meals. The Ae. aegypti mosquito is highly anthropophilic; therefore, it feeds predominantly on humans (Liebman et al., 2014) and seldom supplements blood meals with plant sugar (Scott et al., 2000). Attempts to understand which members of the population are more likely to be bitten by the mosquito have remained inconclusive. However, factors that appear to increase the likelihood of bites include larger body size, due to increased heat signature and CO2 production, as well as decreased human movement (Liebman et al., 2014).

Compared to other mosquito species that typically ingest one blood meal per ovarian cycle, the female Ae. aegypti mosquito is unique in that it will ingest multiple blood meals throughout a gonotrophic cycle (Scott et al., 2000). This behavior is known as multiple feeding, and as the number of blood meals increases, the rate of transmission for vectorborne pathogens can potentially exponentially increase as well (Scott \& Takken, 2012). There is a negative relationship between body size and multiple feedings; that is, smaller females will require more blood meals to improve their fecundity, thereby increasing their contact with hosts (Farjana \& Tuno, 2013). Previous studies have established a negative relationship between temperature and body size due to shortened development time (Mohammed \& Chadee, 2011; Tun-lin et al., 2000), suggesting that an increase in temperature would eventually lead to an increase in the frequency of blood meals. Female Ae. aegypti 
mosquitoes were found to partake in higher instances of blood-feeding between $26^{\circ} \mathrm{C}$ and $35^{\circ} \mathrm{C}$ (Reinhold et al., 2018). This is especially disconcerting when considering that as temperatures pass $25^{\circ} \mathrm{C}$, the sex ratio in Ae. aegypti larvae show significantly more females emerging (Mohammed \& Chadee, 2011). An increase in the number of smaller females requiring a higher frequency of blood meals would ostensibly lead to heightened contact with hosts, consequently increasing the likelihood of pathogen transmission. Indeed, increased contact between humans and Ae. aegypti populations have been associated with the dramatic rise in the incidence rate of DENV and YFV in recent decades (Monath, 1994).

\subsection{Development}

Aside from the previously established negative relationship with body mass, increasing temperatures have further effects on the development of the Ae. aegypti mosquito. The eggs of the Ae. aegypti have a unique property in that they hatch simultaneously when exposed to water, as opposed to irregularly, as is the case in other species of mosquitoes. This property lends itself well to rapid population growth and will likely aid the Ae. aegypti in establishing colonies in new niches. Indeed, data suggests it may be able to find success in areas where the temperature is in the range of $25-35^{\circ} \mathrm{C}$ (Farjana et al., 2011). The rate at which females lay eggs increases as temperatures rise, leading to a more substantial amount of eggs being laid more frequently (Yang et al., 2009).

The adult mortality rate begins to increase exponentially at $35^{\circ} \mathrm{C}$, suggesting that it may be the upper limit for the vector. Similarly, at $25^{\circ} \mathrm{C}$, larvae begin to experience higher mortality rates. The probability of surviving from egg to adulthood diminishes past $25^{\circ} \mathrm{C}$ and vanishes completely upon nearing $40^{\circ} \mathrm{C}$ (Moustaid \& Johnson, 2019).

Mosquitoes use a variety of methods to locate a host, such as thermal and chemical detection, and as such, flight activity is intrinsically linked to their success in blood-feeding. Data suggests that the temperature range in which the female Ae. aegypti can fly sustainably is $15-35^{\circ} \mathrm{C}$, with the optimal temperature appearing to be around $21^{\circ} \mathrm{C}$ (Reinhold et al., 2018). Humidity has been shown to have little to no effect on flight performance (Rowley \& Graham, 1968). This illustrates a broad spectrum of temperatures in which the female Ae. aegypti can fly reliably in pursuit of blood meals. Female Ae. aegypti mosquitoes use a specific frequency of wing-beats to attract a mate, and this frequency has likewise been shown to vary with ambient temperature. Notably, there is a linear relationship, with frequency increasing between $8-13 \mathrm{~Hz}$ for every degree ${ }^{\circ} \mathrm{C}$ and male Ae. aegypti were shown to react more favorably to higher frequencies (Villarreal et al., 2017). This implies adaptability to improve the chances of mating during times of abiotic stress in order to increase fitness.

\subsection{Spatial Distribution}

The natural niche of the Aedes aegypti mosquito has primarily been dictated by its inability to survive below $10^{\circ} \mathrm{C}$ and above $40^{\circ} \mathrm{C}$ (Reinhold et al., 2018). This has historically afforded regions outside of that range inherent protection; however, reports suggest that temperate zones formerly outside the endemic range are among the most at risk of being negatively 
impacted by climate change (Rohr et al., 2011). In the past century, a 30\% increase in CO2 production raised global surface temperatures by $0.5^{\circ} \mathrm{C}$ (Wigley et al., 1992). Minimum temperatures are increasing disproportionately, and current climate change predictions expect this trend to continue. Such scenarios could increase the epidemic potential in regions previously unburdened by disease (Patz et al., 1998). The Ae. aegypti mosquito primarily resides within latitudes $32^{\circ} \mathrm{N}$ to $32^{\circ} \mathrm{S}$, and projection models estimate that that will soon expand to $35^{\circ} \mathrm{N}$ to $35^{\circ} \mathrm{S}$ (Alaniz et al., 2018). Current statistical models predict the Ae. aegypti mosquito will be able to establish itself in at least three new countries by 2080, bringing its spatial distribution to 159 countries total (Kraemer et al., 2019). This would potentially put $49 \%$ of the global population at risk of arboviral transmission (Kraemer et al., 2019). Given the mosquito's peridomestic preferences and ability to lay eggs in small amounts of water, it will not be much affected by changing precipitation levels or decreased vegetation (Kraemer et al., 2015). Previous studies have established that domestic water storage practices are more significant predictors of mosquito reproduction than rainfall (Southwood et al., 1972).

Presently, an estimated 100 million people are infected annually by the Ae. aegypti mosquito (Messina et al., 2019), and this number is predicted to increase to close to a billion by the end of the century (Ryan et al., 2019). The population at risk may be significantly lowered if climate policy, such as the Paris Agreement (UNFCCC), is enforced to limit global warming to below $2^{\circ} \mathrm{C}$ (Liu-Helmersson et al., 2019). Reducing the emission of greenhouse gases will limit the increase of the Ae. aegypti's expansion, and in turn, limit the burden of disease in the areas it inhabits (Kraemer et al., 2019).

\section{Methods}

\subsection{Search Criteria}

We conducted a systematic search in the PubMed database for articles that assessed the relationship between temperature and the vectorial capacity of the Aedes aegypti mosquito. Search parameters specified English or Spanish languages and publication dates between January 1, 1988, and March 30, 2020. We developed the search strategy using the synonymous search terms provided in Appendix 1. Studies that did not include climate change as an element of analysis were excluded. Studies before 1988 were excluded to restrict the results to the current era of climate change, which is defined as the year the Intergovernmental Panel on Climate Change (IPCC) first convened (Huq \& Toulmin, 2006). Studies without full-text availability were not excluded. We used Zotero to manage studies and data.

\subsection{Study Design}

For this study, we utilized a systematic map approach to assess the current state of research on this topic and followed the recommendations made by the Social Care Institute for Excellence (Bates et al., 2007) as well as the Preferred Reporting Items for Systematic Reviews and Meta-Analyses (Moher et al., 2009). The search strategy was not limited by 
article study design. Studies were only eligible for inclusion if they met the following criteria: the study population was the Aedes aegypti mosquito; the effect of climate change on the Aedes aegypti was examined; and the outcome was an influence on the mosquito's vectorial capacity.

\subsection{Data Extraction}

One reviewer (LM) screened titles and abstracts using DistillerSR, then screened the included full-text articles. One reviewer (LM) subsequently extracted the geographical region and country the study was based in, the study characteristics, then evaluated the quality of the study and recorded the data in a standard form. Only studies that evaluated climate change's potential effect on the Ae. aegypti population were used in the analysis, while studies that only focused on temperature outside of the context of climate change were excluded. All articles were grouped according to the region in which the study occurred.

\section{Results}

Our initial search in PubMed yielded 1058 articles after the removal of duplicates, and 503 remained after the full-text screening (Figure 1). Only 83 articles met the inclusion criteria and were subsequently included in the analysis (Table 1). [Appendix].

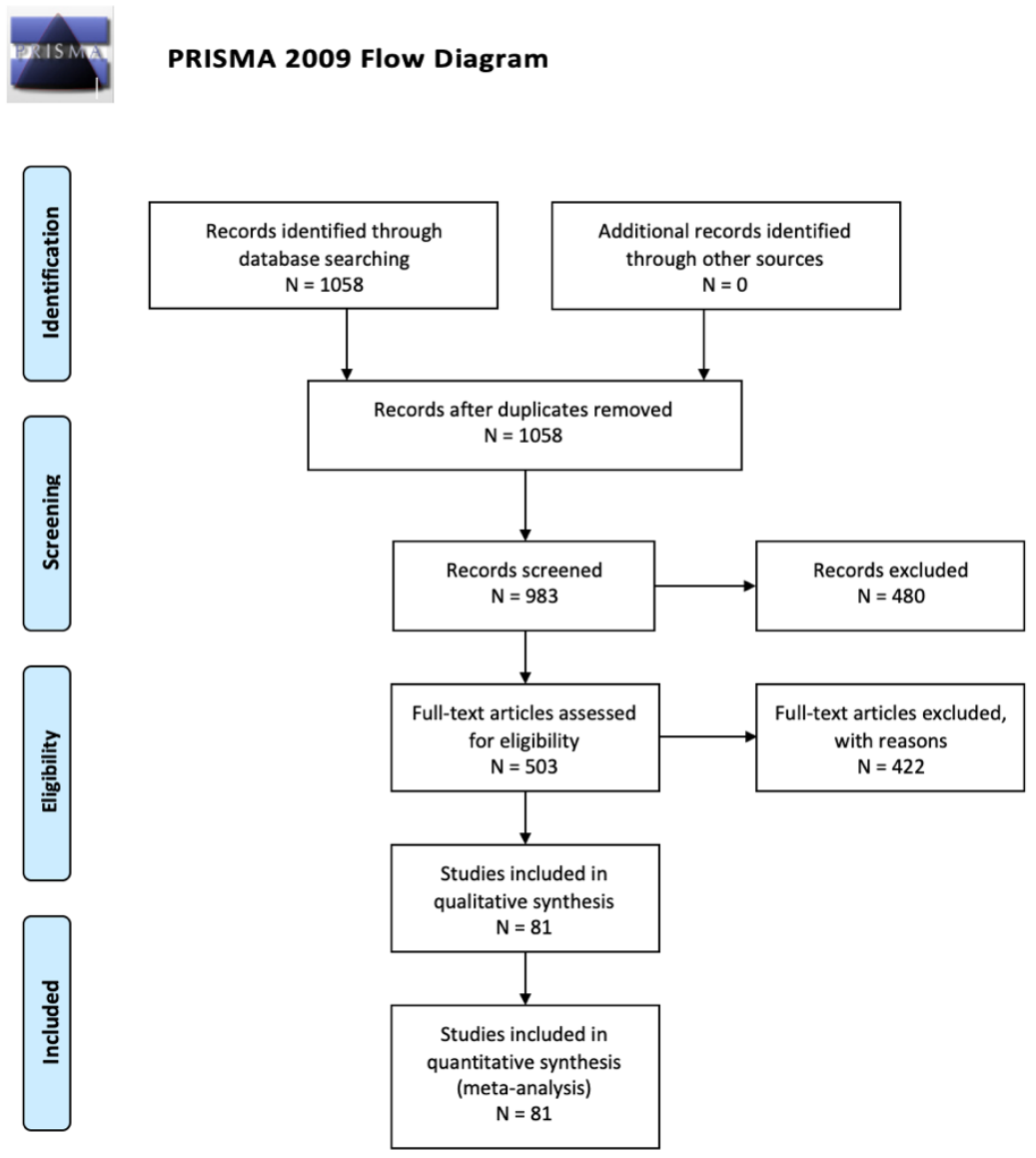


Although our inclusion criteria set the publication date to be from 1988 to 2020, most of the included studies were published in late 2000 and on. Fig. 2 illustrates the quantity of included studies per publication year. There was a significant increase in the number of studies published on this topic in 2019.

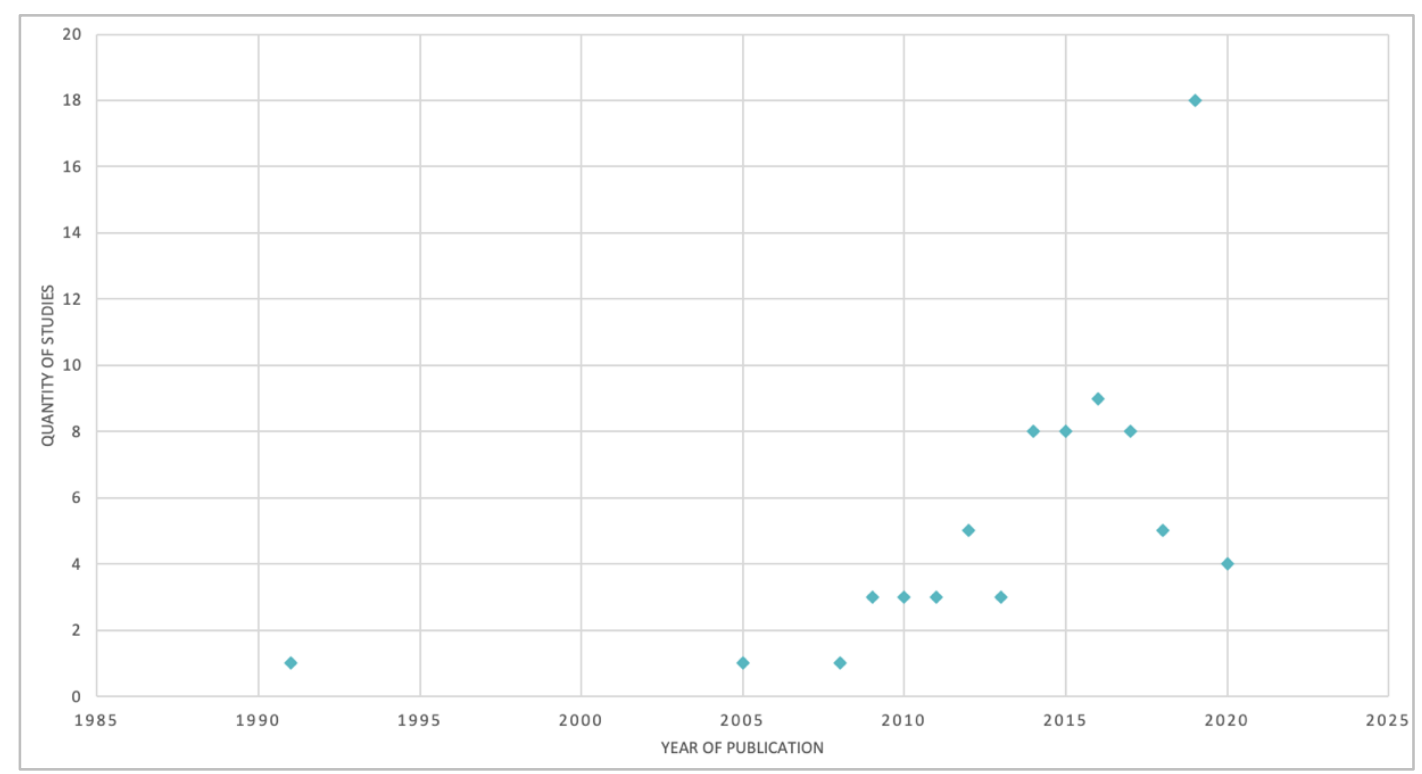

Figure 2: Publication dates and quantity of studies included in analysis

Asia and North America were the regions with the highest number of published articles $(\mathrm{n}=$ 23, 28\%; $n=15,18 \%)$, followed by Europe ( $n=14 ; 17 \%)$. [Figure 3]. In South America, most of the studies were on Brazil or Argentina ( $n=2 ; 20 \%)$, but overall only five of thirteen countries in South America were represented in the literature [Figure. 4]. The Ae. aegypti mosquito is endemic in thirteen South American countries (Leta et al., 2018), yet no literature was included in the analysis that focused on eight of those countries. This leaves $62 \%$ of South America unrepresented. The areas in South America most heavily impacted by the Ae. aegypti are Brazil, Colombia, and Venezuela (Torres \& Castro, 2006), yet Colombia and Venezuela were not well represented in the literature.

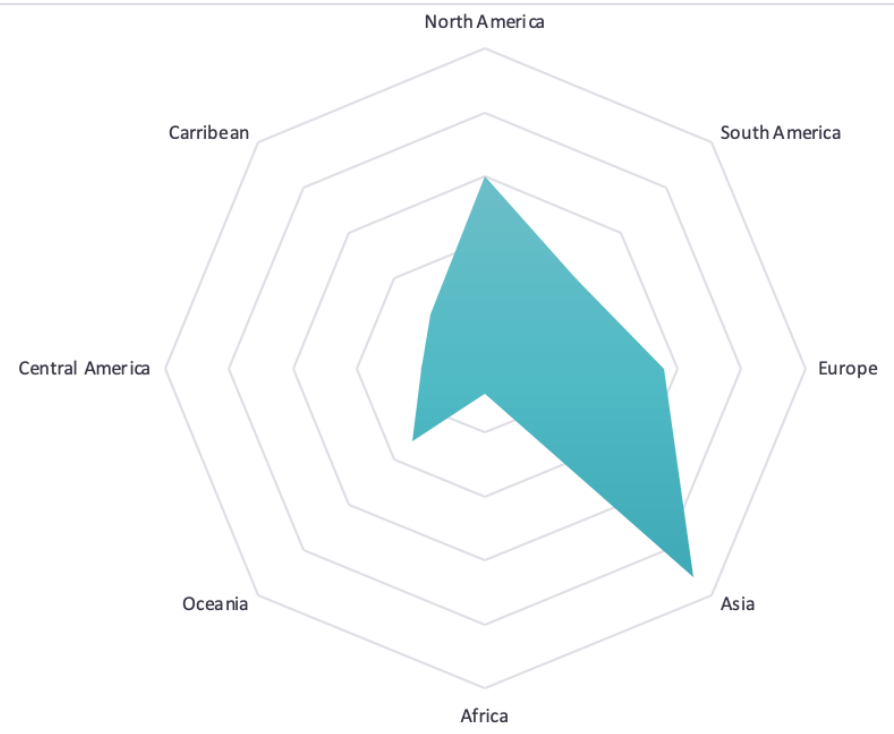




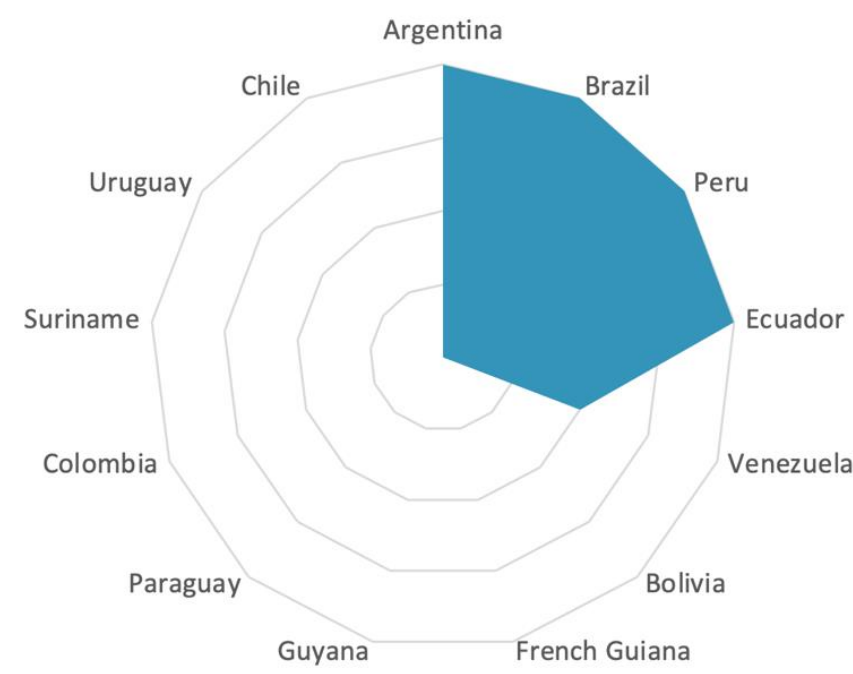

Figure 4: Spider map of South American countries represented in included studies

\section{Discussion}

The use of spider maps is an effective tool for summarizing the relative proportions of a measure across multiple dimensions. The spider maps included here illustrate, clearly, that the intellectual production on this important issue is limited. The results of a systematic review of the literature are quickly illuminated through these illustrative methods. As represented in Fig. 3, the literature is produced in only some regions of the world. This is important because climate change is predicted to disproportionately impact developing countries, and thus it is critical to understand how these areas will be affected by this topic (United Nations, 2019). In Fig. 4 we see that though South America suffers a significant burden of disease from this vector, the scientific work on the topic is limited. The spider map can quickly convey the gaps in knowledge and unmet need that faces South America.

With $70 \%$ of the global dengue burden affecting Asia, it was not surprising that the area would be well represented in the literature (Bhatt et al., 2013). Conversely, despite Aedesborne arboviruses ravaging many areas of Africa, they were poorly represented in the literature (Weetman et al., 2018). This may be due to several factors, including the misclassification of many fevers as malaria in regions where the public health infrastructure lacks resources (Stoler et al., 2013). North America and Europe both had strong representation in the current literature, despite not being under significant threat from the Aedes aegypti mosquito yet, compared to the other regions (CDC, 2020). South America was not far ahead of neighboring regions Central America and the Caribbean, which had similar numbers of literature captured, although it should be noted that South America is the subregion most impacted by the Ae. aegypti in Latin America and the Caribbean (LAC) (Torres \& Castro, 2006).

While under-represented in the literature, it is worthwhile to establish estimates of the impact of these infectious diseases. It is difficult to find statistics on South America alone, as the continent is generally grouped together with the other components of LAC when publishing reports. In 2016, the Americas reported 2.38 million cases of dengue, of which 
1.5 million were reported in Brazil alone (WHO, 2020). The economic cost this burden of disease presents on the health care systems in this region is significant. In 2010, the total cost induced by dengue fever alone in South America was approximately USD 1.4 billion (Shepard et al., 2011). The 2009 epidemic in Argentina cost approximately USD 10.7 million (Cafferata et al., 2013). The public healthcare systems in LAC are overburdened and overstressed, in addition to being largely underfunded. With these systems already overwhelmed by ongoing health emergencies due to tuberculosis (TB), DENV, and YFV, an increase in the burden of disease will strain the capabilities of LAC healthcare (Litewka \& Heltman, 2020).

Several of the diseases the Aedes aegypti transmits have been classified as NTDs due to their strong correlation with poverty $(\mathrm{WHO}, 2010)$; therefore, it is essential to note that poverty is high in LAC, with approximately $30.8 \%$ of the population living below the poverty line, and $11.5 \%$ living in extreme poverty (ECLAC, 2019). Furthermore, $76.8 \%$ of the population falls into low-income to lower-middle-income brackets (ECLAC, 2019). These numbers are comparable in South America, with $23.3 \%$ and $6.4 \%$ of its population living in poverty and extreme poverty, respectively (CEPAL, 2019). That translates to around 184 million people living in poverty in that region (ECLAC, 2019). While regions such as Africa or Asia also have high instances of poverty, LAC is unique in that it has the highest income inequality in the world (Belizán et al., 2007). The impact of the COVID-19 pandemic on the region is expected to result in the worst recession in a century, leading to further inequality (United Nations, 2020).

The burden of disease in South America is confounded with high poverty rates and the inequality affecting vulnerable populations. In particular, indigenous populations tend to be disproportionately affected by vector-borne infectious diseases that arise during conflict (Hotez et al., 2008). The healthcare systems in LAC are segmented and fractured, which poses a major obstacle in increasing access to healthcare, particularly for those from lower socioeconomic status (Frenk \& Gómez-Dantés, 2018). In many LAC countries, healthcare for those living in poverty is provided by a Ministry of Public Health, which is often poorly financed and historically has provided lower quality of care compared to the services provided by the private sector (Cotlear et al., 2014). With the COVID-19 pandemic expected to impact the most disadvantaged populations disproportionately, reform will be necessary to prepare for future crises (Busso \& Messina, 2020).

\section{Limitations}

This study was limited by restricting the search to a single database and would benefit from an expanded search into multiple databases. In particular, a cursory search into Spanish language databases during the literature review found several studies that were not captured in PubMed. In addition, much of the data was constricted by the grouping of South America into LAC, and searches in Spanish had to be made in order to find the necessary conclusions.

\section{Conclusion}


By the end of the century, if nothing is done to limit climate change, it is predicted that close to a billion people annually are at risk of being infected by the Aedes aegypti mosquito (Ryan et al., 2019). Much of this will occur in developing countries, impacting agriculture, water availability, increasing the incidence of vector-borne diseases, and damage the GDP (Ravindranath \& Sathaye, 2002). With its high rate of poverty and inequality, South America will be especially vulnerable to the expanded range and improved vector capacity of the Aedes aegypti mosquito. Compared to regions such as Asia or North America, South America does not appear to be as well represented in the current literature on this topic. It is clear from our results that more research is needed to be conducted on South America in order to fully understand how this region, in particular, will be affected in the coming century.

Author Contributions: Conceptualization, L.M. and R.D.L.; methodology, L.M. and. R.D.L.; software, L.M. and R.D.L.; validation, L.M. and R.D.L.; formal analysis, L.M.; investigation, L.M.; resources, R.D.L.; data curation, L.M. and R.D.L.; writing-original draft preparation, L.M.; writing-review and editing, L.M. and R.D.L.; visualization, L.M.; supervision, R.D.L.; project administration, R.D.L.; funding acquisition, L.M. All authors have read and agreed to the published version of the manuscript.

Acknowledgments: We thank the McNair Scholar Program for their funding and support.

Conflicts of Interest: The authors declare no conflict of interest.

\section{References}

1. Kraemer, M. U., Sinka, M. E., Duda, K. A., Mylne, A. Q., Shearer, F. M., Barker, C. M., Moore, C. G., Carvalho, R. G., Coelho, G. E., Van Bortel, W., Hendrickx, G., Schaffner, F., Elyazar, I. R., Teng, H.-J., Brady, O. J., Messina, J. P., Pigott, D. M., Scott, T. W., Smith, D. L., .. Hay, S. I. (2015). The global distribution of the arbovirus vectors Aedes aegypti and Ae. Albopictus. ELife, 4. https://doi.org/10.7554/eLife.08347

2. Chang, C., Ortiz, K., Ansari, A., \& Gershwin, M. E. (2016). The Zika outbreak of the 21st century. Journal of Autoimmunity, 68, 1-13. https://doi.org/10.1016/j.jaut.2016.02.006

3. Borgherini, G., Poubeau, P., Staikowsky, F., Lory, M., Le Moullec, N., Becquart, J. P., Wengling, C., Michault, A., \& Paganin, F. (2007). Outbreak of chikungunya on Reunion Island: Early clinical and laboratory features in 157 adult patients. Clinical Infectious Diseases: An Official Publication of the Infectious Diseases Society of America, 44(11), 1401-1407. https://doi.org/10.1086/517537

4. Nogueira, R. M. R., Schatzmayr, H. G., Bispo de Filippis, A. M., Barreto dos Santos, F., Venâncio da Cunha, R., Coelho, J. O., José de Souza, L., Guimarães, F. R., Machado de Araújo, E. S., De Simone, T. S., Baran, M., Teixeira, G., \& Miagostovich, M. P. (2005). Dengue Virus Type 3, Brazil, 2002. Emerging Infectious Diseases, 11(9), 1376-1381. https://doi.org/10.3201/eid1109.041043

5. Mohammed, A., \& Chadee, D. D. (2011). Effects of different temperature regimens on the development of Aedes aegypti (L.) (Diptera: Culicidae) mosquitoes. Acta Tropica, 119(1), 38-43. https://doi.org/10.1016/j.actatropica.2011.04.004 
6. Powell, J. R., \& Tabachnick, W. J. (2013). History of domestication and spread of Aedes aegyptiA Review. Memórias Do Instituto Oswaldo Cruz, 108(suppl 1), 11-17. https://doi.org/10.1590/0074$\underline{0276130395}$

7. Brown, J. E., Evans, B. R., Zheng, W., Obas, V., Barrera-Martinez, L., Egizi, A., Zhao, H., Caccone, A., \& Powell, J. R. (2014). Human impacts have shaped historical and recent evolution in Aedes aegypti, the dengue and yellow fever mosquito. Evolution; International Journal of Organic Evolution, 68(2), 514-525. https://doi.org/10.1111/evo.12281

8. Moncayo, A. C., Fernandez, Z., Ortiz, D., Diallo, M., Sall, A., Hartman, S., Davis, C. T., Coffey, L., Mathiot, C. C., Tesh, R. B., \& Weaver, S. C. (2004). Dengue Emergence and Adaptation to Peridomestic Mosquitoes. Emerging Infectious Diseases, 10(10), 1790-1796. https://doi.org/10.3201/eid1010.030846

9. Lippi, C. A., Stewart-Ibarra, A. M., Loor, M. E. F. B., Zambrano, J. E. D., Lopez, N. A. E., Blackburn, J. K., \& Ryan, S. J. (2019). Geographic shifts in Aedes aegypti habitat suitability in Ecuador using larval surveillance data and ecological niche modeling: Implications of climate change for public health vector control. PLoS Neglected Tropical Diseases, 13(4). https://doi.org/10.1371/journal.pntd.0007322

10. Kantor, I. N. (2018). Dengue, zika, chikungunya y el desarrollo de vacunas. Medicina, 78(1), 2328.

11. Messina, J. P., Brady, O. J., Pigott, D. M., Golding, N., Kraemer, M. U. G., Scott, T. W., Wint, G. R. W., Smith, D. L., \& Hay, S. I. (2015). The many projected futures of dengue. Nature Reviews. Microbiology, 13(4), 230-239. https://doi.org/10.1038/nrmicro3430

12. WHO | World Health Organization. (n.d.). WHO; World Health Organization. Retrieved October 4, 2020, from http://www.who.int/neglected_diseases/diseases/en/

13. Vanderslott, S. (2019). Moving From Outsider to Insider Status Through Metrics: The Inclusion of "Neglected Tropical Diseases" Into the Sustainable Development Goals. Journal of Human Development and Capabilities, 20(4), 418-435. https://doi.org/10.1080/19452829.2019.1574727

14. Franco-Paredes, C., Jones, D., Rodríguez-Morales, A. J., \& Santos-Preciado, J. I. (2007). Commentary: Improving the health of neglected populations in Latin America. BMC Public Health, 7, 11. https://doi.org/10.1186/1471-2458-7-11

15. Brady, O. J., Johansson, M. A., Guerra, C. A., Bhatt, S., Golding, N., Pigott, D. M., Delatte, H., Grech, M. G., Leisnham, P. T., Maciel-de-Freitas, R., Styer, L. M., Smith, D. L., Scott, T. W., Gething, P. W., \& Hay, S. I. (2013). Modelling adult Aedes aegypti and Aedes albopictus survival at different temperatures in laboratory and field settings. Parasites $\mathcal{E}$ Vectors, 6(1), 351. https://doi.org/10.1186/1756-3305-6-351

16. Weaver, S. C. (2014). Arrival of Chikungunya Virus in the New World: Prospects for Spread and Impact on Public Health. PLoS Neglected Tropical Diseases, 8(6). https://doi.org/10.1371/journal.pntd.0002921

17. Solomon, S., Intergovernmental Panel on Climate Change, \& Intergovernmental Panel on Climate Change (Eds.). (2007). Climate change 2007: The physical science basis: contribution of Working Group I to the Fourth Assessment Report of the Intergovernmental Panel on Climate Change. Cambridge University Press. https://www.ipcc.ch/site/assets/uploads/2018/03/ar4 wg3 full report-1.pdf 
18. Scott, T., Amerasinghe, P., Morrison, A., Lorenz, L., Clark, G., Strickman, D., Kittayapong, P., \& Edman, J. (2000). Longitudinal Studies of Aedes aegypti (Diptera: Culicidae) in Thailand and Puerto Rico: Blood Feeding Frequency. Journal of Medical Entomology, 37(1), 89-. Gale Academic

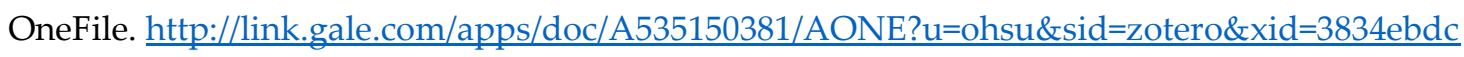

19. Farjana, T., Tuno, N., \& Higa, Y. (2012). Effects of temperature and diet on development and interspecies competition in Aedes aegypti and Aedes albopictus. Medical and Veterinary Entomology, 26(2), 210-217. https://doi.org/10.1111/j.1365-2915.2011.00971.x

20. El Moustaid, F., \& Johnson, L. R. (2019). Modeling Temperature Effects on Population Density of the Dengue Mosquito Aedes aegypti. Insects, 10(11), 393. https://doi.org/10.3390/insects10110393

21. Reinhold, J. M., Lazzari, C. R., \& Lahondère, C. (2018). Effects of the Environmental Temperature on Aedes aegypti and Aedes albopictus Mosquitoes: A Review. Insects, 9(4). https://doi.org/10.3390/insects9040158

22. Culbert, N. J., Gilles, J. R. L., \& Bouyer, J. (2019). Investigating the impact of chilling temperature on male Aedes aegypti and Aedes albopictus survival. PLoS ONE, 14(8). https://doi.org/10.1371/journal.pone.0221822

23. Winokur, O. C., Main, B. J., Nicholson, J., \& Barker, C. M. (2020). Impact of temperature on the extrinsic incubation period of Zika virus in Aedes aegypti. PLOS Neglected Tropical Diseases, 14(3), e0008047. https://doi.org/10.1371/journal.pntd.0008047

24. Alonso-Palomares, L. A., Moreno-García, M., Lanz-Mendoza, H., \& Salazar, M. I. (2018). Molecular Basis for Arbovirus Transmission by Aedes aegypti Mosquitoes. Intervirology, 61(6), 255-264. https://doi.org/10.1159/000499128

25. Lequime, S., \& Lambrechts, L. (2014). Vertical transmission of arboviruses in mosquitoes: A historical perspective. Infection, Genetics and Evolution, 28, 681-690. https://doi.org/10.1016/j.meegid.2014.07.025

26. Liebman, K. A., Stoddard, S. T., Reiner, R. C., Perkins, T. A., Astete, H., Sihuincha, M., Halsey, E. S., Kochel, T. J., Morrison, A. C., \& Scott, T. W. (2014). Determinants of Heterogeneous Blood Feeding Patterns by Aedes aegypti in Iquitos, Peru. PLoS Neglected Tropical Diseases, 8(2). https://doi.org/10.1371/journal.pntd.0002702

27. Scott, T. W., \& Takken, W. (2012). Feeding strategies of anthropophilic mosquitoes result in increased risk of pathogen transmission. Trends in Parasitology, 28(3), 114-121. https://doi.org/10.1016/j.pt.2012.01.001

28. Farjana, T., \& Tuno, N. (2013). Multiple blood feeding and host-seeking behavior in Aedes aegypti and Aedes albopictus (Diptera: Culicidae). Journal of Medical Entomology, 50(4), 838846. https://doi.org/10.1603/me12146

29. Tun-Lin, W., Burkot, T. R., \& Kay, B. H. (2000). Effects of temperature and larval diet on development rates and survival of the dengue vector Aedes aegypti in north Queensland, Australia. Medical and Veterinary Entomology, 14(1), 31-37. https://doi.org/10.1046/j.13652915.2000.00207.x 
30. Monath, T. P. (1994). Dengue: The risk to developed and developing countries. Proceedings of the National Academy of Sciences of the United States of America, 91(7), 2395-2400. https://doi.org/10.1073/pnas.91.7.2395

31. Yang, H. M., Macoris, M. L. G., Galvani, K. C., Andrighetti, M. T. M., \& Wanderley, D. M. V. (2009). Assessing the effects of temperature on the population of Aedes aegypti, the vector of dengue. Epidemiology \& Infection, 137(8), 1188-1202. https://doi.org/10.1017/S0950268809002040

32. Rowley, W. A., \& Graham, C. L. (1968). The effect of temperature and relative humidity on the flight performance of female Aedes aegypti. Journal of Insect Physiology, 14(9), 1251-1257. https://doi.org/10.1016/0022-1910(68)90018-8

33. Villarreal, S. M., Winokur, O., \& Harrington, L. (2017). The Impact of Temperature and Body Size on Fundamental Flight Tone Variation in the Mosquito Vector Aedes aegypti (Diptera: Culicidae): Implications for Acoustic Lures. Journal of Medical Entomology, 54(5), 1116-1121. https://doi.org/10.1093/jme/tjx079

34. Rohr, J. R., Dobson, A. P., Johnson, P. T. J., Kilpatrick, A. M., Paull, S. H., Raffel, T. R., RuizMoreno, D., \& Thomas, M. B. (2011). Frontiers in climate change-disease research. Trends in Ecology \& Evolution, 26(6), 270-277. https://doi.org/10.1016/j.tree.2011.03.002

35. Wigley, T. M. L., \& Raper, S. C. B. (1992). Implications for climate and sea level of revised IPCC emissions scenarios. Nature, 357(6376), 293-300. https://doi.org/10.1038/357293a0

36. Patz, J. A., Martens, W. J., Focks, D. A., \& Jetten, T. H. (1998). Dengue fever epidemic potential as projected by general circulation models of global climate change. Environmental Health Perspectives, 106(3), 147-153. https://www.ncbi.nlm.nih.gov/pmc/articles/PMC1533051/

37. Alaniz, A. J., Carvajal, M. A., Bacigalupo, A., \& Cattan, P. E. (2018). Global spatial assessment of Aedes aegypti and Culex quinquefasciatus: A scenario of Zika virus exposure. Epidemiology and Infection, 147, 52. https://doi.org/10.1017/S0950268818003102

38. Kraemer, M. U. G., Reiner, R. C., Brady, O. J., Messina, J. P., Gilbert, M., Pigott, D. M., Yi, D., Johnson, K., Earl, L., Marczak, L. B., Shirude, S., Davis Weaver, N., Bisanzio, D., Perkins, T. A., Lai, S., Lu, X., Jones, P., Coelho, G. E., Carvalho, R. G., ... Golding, N. (2019). Past and future spread of the arbovirus vectors Aedes aegypti and Aedes albopictus. Nature Microbiology, 4(5), 854-863. https://doi.org/10.1038/s41564-019-0376-y

39. Southwood, T. R. E., Murdie, G., Yasuno, M., Tonn, R. J., \& Reader, P. M. (1972). Studies on the life budget of Aedes aegypti in Wat Samphaya, Bangkok, Thailand. Bulletin of the World Health Organization, 46(2), 211-226. https://www.ncbi.nlm.nih.gov/pmc/articles/PMC2480713/

40. Messina, J. P., Brady, O. J., Golding, N., Kraemer, M. U. G., Wint, G. R. W., Ray, S. E., Pigott, D. M., Shearer, F. M., Johnson, K., Earl, L., Marczak, L. B., Shirude, S., Davis Weaver, N., Gilbert, M., Velayudhan, R., Jones, P., Jaenisch, T., Scott, T. W., Reiner, R. C., \& Hay, S. I. (2019). The current and future global distribution and population at risk of dengue. Nature Microbiology, 4(9), 1508-1515. https://doi.org/10.1038/s41564-019-0476-8

41. Ryan, S. J., Carlson, C. J., Mordecai, E. A., \& Johnson, L. R. (2019). Global expansion and redistribution of Aedes-borne virus transmission risk with climate change. PLOS Neglected Tropical Diseases, 13(3), e0007213. https://doi.org/10.1371/journal.pntd.0007213 
42. Liu-Helmersson, J., Stenlund, H., Wilder-Smith, A., \& Rocklöv, J. (2014). Vectorial Capacity of Aedes aegypti: Effects of Temperature and Implications for Global Dengue Epidemic Potential. PLoS ONE, 9(3). https://doi.org/10.1371/journal.pone.0089783

43. Huq, Saleemul, \& Toulmin, Camilla. (2006). Three eras of climate change. United Kingdom.

44. Bates, S., Clapton, J., \& Coren, E. (2007). Systematic maps to support the evidence base in social care. Evidence \& Policy: A Journal of Research, Debate and Practice, 3(4), 539-551. https://doi.org/10.1332/174426407782516484

45. Moher, D., Liberati, A., Tetzlaff, J., Altman, D. G., \& PRISMA Group. (2009). Preferred reporting items for systematic reviews and meta-analyses: The PRISMA statement. PLoS Medicine, 6(7), e1000097. https://doi.org/10.1371/journal.pmed.1000097

46. Leta, S., Beyene, T. J., De Clercq, E. M., Amenu, K., Kraemer, M. U. G., \& Revie, C. W. (2018). Global risk mapping for major diseases transmitted by Aedes aegypti and Aedes albopictus. International Journal of Infectious Diseases: IJID: Official Publication of the International Society for Infectious Diseases, 67, 25-35. https://doi.org/10.1016/j.ijid.2017.11.026

47. Torres, J. R., \& Castro, J. (2007). The health and economic impact of dengue in Latin America. Cadernos de Saúde Pública, 23, S23-S31. https://doi.org/10.1590/S0102-311X2007001300004

48. Unprecedented Impacts of Climate Change Disproportionately Burdening Developing Countries, Delegate Stresses, as Second Committee Concludes General Debate I Meetings Coverage and Press Releases. (n.d.). Retrieved October 4, 2020, from https://www.un.org/press/en/2019/gaef3516.doc.html

49. Bhatt, S., Gething, P. W., Brady, O. J., Messina, J. P., Farlow, A. W., Moyes, C. L., Drake, J. M., Brownstein, J. S., Hoen, A. G., Sankoh, O., Myers, M. F., George, D. B., Jaenisch, T., Wint, G. R. W., Simmons, C. P., Scott, T. W., Farrar, J. J., \& Hay, S. I. (2013). The global distribution and burden of dengue. Nature, 496(7446), 504-507. https://doi.org/10.1038/nature12060

50. Weetman, D., Kamgang, B., Badolo, A., Moyes, C. L., Shearer, F. M., Coulibaly, M., Pinto, J., Lambrechts, L., \& McCall, P. J. (2018). Aedes Mosquitoes and Aedes-Borne Arboviruses in Africa: Current and Future Threats. International Journal of Environmental Research and Public Health, 15(2), 220. https://doi.org/10.3390/ijerph15020220

51. Stoler, J., al Dashti, R., Anto, F., Fobil, J. N., \& Awandare, G. A. (2014). Deconstructing "malaria": West Africa as the next front for dengue fever surveillance and control. Acta Tropica, 134, 5865. https://doi.org/10.1016/j.actatropica.2014.02.017

52. Dengue Around the World I Dengue I CDC. (2020, June 3).

https://www.cdc.gov/dengue/areaswithrisk/around-the-world.html

53. Dengue and severe dengue. (n.d.). Retrieved October 4, 2020, from https://www.who.int/newsroom/fact-sheets/detail/dengue-and-severe-dengue

54. Shepard, D. S., Coudeville, L., Halasa, Y. A., Zambrano, B., \& Dayan, G. H. (2011). Economic Impact of Dengue Illness in the Americas. The American Journal of Tropical Medicine and Hygiene, 84(2), 200-207. https://doi.org/10.4269/ajtmh.2011.10-0503

55. Cafferata, M. L., Bardach, A., Rey-Ares, L., Alcaraz, A., Cormick, G., Gibbons, L., Romano, M., Cesaroni, S., \& Ruvinsky, S. (2013). Dengue Epidemiology and Burden of Disease in Latin 
America and the Caribbean: A Systematic Review of the Literature and Meta-Analysis. Value in Health Regional Issues, 2(3), 347-356. https://doi.org/10.1016/j.vhri.2013.10.002

56. Litewka, S. G., \& Heitman, E. (2020). Latin American healthcare systems in times of pandemic. Developing World Bioethics, 10.1111/dewb.12262. https://doi.org/10.1111/dewb.12262

57. World Health Organization (Ed.). (2010). Working to overcome the global impact of neglected tropical diseases: First WHO report on neglected tropical diseases. Department of Reproductive health and Research, World Health Organization.

58. Naciones Unidas, \& Comisión Económica para América Latina y el Caribe. (2019). Panorama social de América Latina 2019. Comisión Económica para América Latina y el Caribe.

59. Belizán, J. M., Cafferata, M. L., Belizán, M., \& Althabe, F. (2007). Health inequality in Latin America. Lancet (London, England), 370(9599), 1599-1600. https://doi.org/10.1016/S0140$\underline{6736(07) 61673-0}$

60. Policy Brief: The Impact of COVID-19 on Latin America and the Caribbean (July 2020) - World. (n.d.). ReliefWeb. Retrieved October 4, 2020, from https://reliefweb.int/report/world/policy-brief-impactcovid-19-latin-america-and-caribbean-july-2020

61. Hotez, P. J., Bottazzi, M. E., Franco-Paredes, C., Ault, S. K., \& Periago, M. R. (2008). The Neglected Tropical Diseases of Latin America and the Caribbean: A Review of Disease Burden and Distribution and a Roadmap for Control and Elimination. PLoS Neglected Tropical Diseases, 2(9).

https://doi.org/10.1371/journal.pntd.0000300

62. Frenk, J., \& Gómez-Dantés, O. (2018). Health Systems in Latin America: The Search for Universal Health Coverage. Archives of Medical Research, 49(2), 79-83.

https://doi.org/10.1016/j.arcmed.2018.06.002

63. Cotlear, D., Gómez-Dantés, O., Knaul, F., Atun, R., Barreto, I. C. H. C., Cetrángolo, O., Cueto, M., Francke, P., Frenz, P., Guerrero, R., Lozano, R., Marten, R., \& Sáenz, R. (2015). Overcoming social segregation in health care in Latin America. The Lancet, 385(9974), 1248-1259. https://doi.org/10.1016/S0140-6736(14)61647-0

64. The Inequality Crisis: Latin America and the Caribbean at the Crossroads | Publications. (2020).

Retrieved August 17, 2021, from

https://publications.iadb.org/publications/english/document/The-Inequality-Crisis-Latin-

America-and-the-Caribbean-at-the-Crossroads.pdf

65. Climate Change and Developing Countries I Nijavalli H. Ravindranath I Springer. (n.d.). Retrieved October 4, 2020, from https://www.springer.com/gp/book/9781402001048 


\section{Supplementary appendix}

Supplement to: Climate Change Will Increase the Vector Capacity of the Aedes Aegypti in South America 
Supplementary panel 1: Search strategy in PubMed

\section{Climate Change}

1. climate change (MeSh term (Medical Subject Headings)) AND aedes aegypti (key word)

2. climate change (MeSH term) AND dengue (MeSH term)

3. climate change (MeSH term) AND zika virus (MeSH term)

4. climate change (MeSH term) AND chikungunya fever (MeSH term)

5. climate change (MeSH term) AND chikungunya virus (MeSH term)

6. climate change (MeSH term) AND yellow fever (MeSH term)

7. climate change (MeSH term) AND yellow fever virus (MeSH term)

Aedes Aegypti

1. aedes aegypti (key word) AND temperature (key word)

2. aedes aegypti (key word) AND vector capacity (key word)

3. aedes aegypti (key word) AND vector competence (key word) AND temperature (key word)

4. aedes aegypti (key word) AND vector competence (key word)

5. aedes aegypti (key word) AND spatial distribution (key word) 
Supplementary panel 2: Details of 81 publications included in systematic map and analysis

Title

Global climate change

and infectious disease

Seasonal fluctuation of

Aedes aegypti in Chaco

Province, Argentina

Dengue virus-mosquito interactions

Assessing the effects of temperature on the population of Aedes

aegypti

Dengue and climate change in Australia: predictions for the future should incorporate knowledge from the past

Australia's dengue risk driven by human adaptation to climate change

Present and future arboviral threats

magnitude of dengue incidence in Singapore Potential influence of climate variability on dengue incidence registered in a western
Year 2009

2009

Weaver

North

America

Asia 2010

First Author Region Country

South America

North

America

South

America

Brazil

USA

Oceania

Australia

Russell

Beebe

Oceania

Australia

2009

Ling Hii

Singapore

USA

South

Martinez America
Topic

The effects of

climate change on infectious

diseases

The seasonal

fluctuation of Ae.

aegypti with

change in climate

conditions

Mosquito-dengue

infection

dynamics and the role of

temperature

How temperature

affects the

population of Ae.

aegypti

Modeling future

activity of dengue with climate

change using

historical data of

distribution of vector

Future increased risk of Ae. aegypti range expansion in Australia is due to installation to domestic water storing containers Potential future of arboviruses in new geographical regions

How weather influences the increase of dengue incidence The effect of climate variability on dengue incidence 
pediatric Hospital of

Venezuela

Dengue transmission in the Asia-Pacific region: impact of climate 2011

Banu

Asia

Impact of climate

change and socio-

environmental factors

Effects of different temperature regimens on the development of Aedes aegypti mosquitos

The role of climate variability and change in the transmission dynamics and 2011 Thai Asia Vietnam geographic distribution of dengue

Effects of temperature and diet on development and interspecies competition 2012 in Aedes aegypti and Aedes albopictus

Climate-based models for understanding and forecasting dengue 2012 epidemics

Global climate change and its potential impact on disease transmission by salinity-tolerant 2012 Ramasamy Asia Brunei mosquito vectors in coastal zones

The dengue virus mosquito vector Aedes aegypti at high 2012 LozanoFuentes

Central elevation in Mexico

Climate change, population immunity, and hyperendemicity in 2012 the transmission threshold of dengue change on dengue transmission

The effects of increased water temperatures on the development of Ae. aegypti mosquitos

The effect of global climate on the transmission of infectious diseases

How temperature and diet affect development in tow aedine species

Analyze and model the relationship between climatic factors and dengue outbreaks

The impact of rising sea levels on mosquito vectors

Climate warming could lead to Ae. aegypti proliferating in high-elevation communities The effects of temperature change, population immunity, and 
hyperendemicity on mosquito density

Cooler temperatures

destabilize RNA

interference and increase susceptibility

of disease vector

mosquitoes to viral

infection

Climate and dengue transmission: evidence and implications

The effects of weather and climate change on dengue

Vectorial capacity of Aedes aegypti: effects of temperature and implications for global dengue epidemic potential

Macroclimate determines the global range limit of Aedes aegypti

Climate change and dengue: a critical and systematic review of quantitative modelling approaches

Climate change and the potential global distribution of Aedes aegypti: spatial 2014 2014

LiuHelmersson

North

America

USA

2014

Colón-

González

Central

America

Mexico

Climate variables may influence mosquito-borne viral diseases by way of affecting the antiviral immunity of vectors

Climate change affects dengue transmission in complex ways The influence weather has on dengue incidence

The role diurnal temperature range (DTR) plays in dengue epidemics

The distribution of the Ae. aegypti may increase in the future if new domestic environments become available

The risk of dengue associated with climate change

The risk of climate change on the spatial distribution of Ae. aegypti

and CLIMEX

Spatio-temporal distribution of dengue and lymphatic filariasis vectors along an

Khormi

Asia

Saudi Arabia

Increasing temperatures altitudinal transect in Central Nepal 
Climate change and the emergence of vectorborne diseases in Europe: case study of dengue fever

Assessing climate variability effects on dengue incidence in San Juan, Puerto Rico

Bionomic response of Aedes aegypti to two future climate change scenarios in far north Queensland, Australia: implications for dengue outbreaks

Dengue: recent past and future threats

Climate change influences on global distributions of dengue and chikungunya virus vectors

Risk factors for the presence of chikungunya and dengue vectors, their altitudinal distribution and climatic determinants of their abundance in central Nepal

Clustering, climate and dengue transmission

Junxiong

Asia

Singapore

Spatial models for prediction and early warning of Aedes aegypti proliferation from data on climate change and variability in Cuba distribution of Ae.

aegypti

Estimating dengue risk in Europe under various climate change scenarios Evaluating the possible impact of climate change on dengue transmission

Investigating impacts of future climate change on dengue virus transmission

Discussion on statistical dengue models

Global potential distributions of virus vectors in relation to climatic variation

Climatic variables as predictors of virus vectors abundance

Climatic and nonclimatic risk factors of dengue transmission

Models for predicting spatial distribution patterns of Ae. aegypti based on climate variability 
Climate change and spatiotemporal distributions of vectorborne diseases in Nepal
A systematic review on the effect of climate change on the spatial and temporal distribution of disease vectors

Increasing dengue incidence in Singapore over the past 40 years: 2015 Rocklöv Asia Singapore population growth, climate and mobility Socio-economic and climate factors associated with dengue fever spatial heterogeneity: a worked example in $\mathrm{New}$

Caledonia

The interrelationship between dengue incidence and diurnal ranges of temperature and humidity in a Sri Lankan city and its potential applications Aedes aegypti in Latin American and Caribbean region: with growing evidence for vector adaptation to climate change?

Urban climate versus global climate change what makes the 2015 Teurlai Europe France Evaluating the main drivers for the increase in dengue incidence

The factors affecting the spatial and temporal distribution of dengue

Determining the correlation between diurnal temperature fluctuation and dengue incidence

The impact of climate change on ecology of Ae. aegypti

Urban DTR as a 2016 Misslin Europe France predictor for dengue incidence difference for dengue? Climate change and Aedes vectors: $21^{\text {st }}$ century projections for dengue transmission in 2016 Liu-
Helmersson How increasing temperatures may increase the spread of vectorborne disease Predicting changes in

Projections of increased and decreased dengue incidence under climate 2016 Williams Oceania Australia dengue transmission due to climate change 
Dengue in a changing climate

Climate change and the arboviruses: lessons from the evolution of the dengue and yellow fever viruses

The correlation between dengue incidence and diurnal ranges of temperature of

Colombo district, Sri

Lanka

Climate change influences potential distribution of infected Aedes aegypti cooccurrence with dengue epidemics risk areas in Tanzania An analysis of the potential impact of climate change on dengue transmission in the southeastern United States

Declining prevalence of disease vectors under climate change 2016

2016 2016

Ebi

North

America

USA

North

2016

Tabachnick

America

USA

Asia

Sri Lanka

Evaluating potential changes to dengue transmission due to climate change

Evaluating the potential impact of climate change on arboviruses

Determining the correlation between DTR and dengue incidence

Estimating potential Mweya

Africa

Tanzania distribution of dengue epidemic risk areas

Projected shifts in dengue

North

America

USA transmission risk driven by climate change

Climate change may be threating certain vector species with extinction Development of a

Global risk model for vector borne transmission of zika virus reveals the role of 2016 Caminade

Europe

United Ro mathematical

El Niño 2015

Joint efforts of climate variability and socioecological factors on dengue 2017 Akter

Oceania Australia Kingdom model for transmission risk of ZIKV driven by climate

Assessing the epidemiological evidence on how transmission: epidemiological evidence 


\begin{tabular}{|c|c|c|c|c|c|}
\hline & & & & & $\begin{array}{l}\text { dengue } \\
\text { transmission }\end{array}$ \\
\hline $\begin{array}{l}\text { Modelling the effects of } \\
\text { global climate change } \\
\text { on chikungunya } \\
\text { transmission in the } 21^{\text {st }} \\
\text { century }\end{array}$ & 2017 & Tjaden & Europe & Germany & $\begin{array}{l}\text { Modelling } \\
\text { projections of } \\
\text { how climate } \\
\text { change will } \\
\text { impact } \\
\text { chikungunya } \\
\text { transmission in } \\
\text { new areas }\end{array}$ \\
\hline $\begin{array}{l}\text { Dengue burden in } \\
\text { India: recent trends and } \\
\text { importance of climatic } \\
\text { parameters }\end{array}$ & 2017 & Mutheneni & Asia & India & $\begin{array}{l}\text { Evaluating the } \\
\text { various } \\
\text { interactions } \\
\text { influenced by } \\
\text { climate change } \\
\text { that drive dengue } \\
\text { transmission }\end{array}$ \\
\hline $\begin{array}{l}\text { Outbreaks caused by } \\
\text { Aedes aegyptis due to } \\
\text { El Niño in a coastal area } \\
\text { of Peru }\end{array}$ & 2018 & Ruiz & $\begin{array}{l}\text { South } \\
\text { America }\end{array}$ & Peru & $\begin{array}{l}\text { Analyzing the } \\
\text { impact El Niño } \\
\text { had in the } \\
\text { incidence of } \\
\text { dengue }\end{array}$ \\
\hline $\begin{array}{l}\text { Climate change and } \\
\text { dengue fever } \\
\text { transmission in China: } \\
\text { evidence and challenges }\end{array}$ & 2017 & $\mathrm{Li}$ & Asia & China & $\begin{array}{l}\text { Summarizing } \\
\text { empirical } \\
\text { evidence on } \\
\text { dengue impacted } \\
\text { by climate change }\end{array}$ \\
\hline $\begin{array}{l}\text { Present and future of } \\
\text { dengue fever in Nepal: } \\
\text { mapping climatic } \\
\text { suitability by ecological } \\
\text { niche model }\end{array}$ & 2018 & Acharya & Asia & Nepal & $\begin{array}{l}\text { Understanding } \\
\text { potential range } \\
\text { shift of dengue } \\
\text { risk areas due to } \\
\text { climate change }\end{array}$ \\
\hline $\begin{array}{l}\text { Environmental factors } \\
\text { can influence dengue } \\
\text { reported cases }\end{array}$ & 2017 & Carneiro & $\begin{array}{c}\text { South } \\
\text { America }\end{array}$ & Brazil & $\begin{array}{l}\text { Global climate } \\
\text { change } \\
\text { contributes to } \\
\text { increases in } \\
\text { arbovirus } \\
\text { transmission }\end{array}$ \\
\hline $\begin{array}{l}\text { The potential impacts of } \\
21^{\text {st }} \text { century climatic and } \\
\text { population changes on } \\
\text { human exposure to the } \\
\text { virus vector mosquito } \\
\text { Aedes aegypti }\end{array}$ & 2018 & Monaghan & $\begin{array}{l}\text { North } \\
\text { America }\end{array}$ & USA & $\begin{array}{l}\text { How choosing } \\
\text { alternative } \\
\text { socioeconomic } \\
\text { pathways will } \\
\text { influence Ae. } \\
\text { aegypti exposure } \\
\text { in the future }\end{array}$ \\
\hline $\begin{array}{l}\text { Limiting global-mean } \\
\text { temperature increase to } \\
1.5-2{ }^{\circ} \mathrm{C} \text { could reduce }\end{array}$ & 2018 & $\begin{array}{l}\text { Colón- } \\
\text { González }\end{array}$ & $\begin{array}{l}\text { Latin } \\
\text { America }\end{array}$ & Multiple & $\begin{array}{l}\text { Model for } \\
\text { predicting the }\end{array}$ \\
\hline
\end{tabular}


the incidence and

spatial spread of

dengue fever in Latin

America

Effects of the

environmental

temperature on Aedes

aegypti and Aedes

2018

albopictus mosquitos: a

review

Past, present and future

of Aedes aegypti in its

South American

southern distribution

fringe: what do

temperature and

population tell us?

Mapping the global

potential distributions

of two arboviral vectors

Aedes aegypti and Ae.

albopictus under

changing climate

Modeling the present and future distribution

of arbovirus vectors

Aedes aegypti and

2019

Liu

Aedes albopictus under

climate change

Dengue fever in Punjab,

Pakistan: knowledge,

perception, and

2018

adaption among urban

adults

Urban and semi-urban

mosquitoes of Mexico

City: a risk for endemic

mosquito-borne disease

transmission

Climate change may

enable Aedes aegypti

infestation in major

European cities by 2100
Asia

China

impact of climate

change on dengue

A review on the

effect of

North

America

USA

temperature on

two mosquito

vectors

How human

population and

air temperature

correlated with

spatial

distribution of Ae.

aegypti

Assessing the

influence climate

change will have

on spatial

distribution of

two mosquito

vectors

Modeling

predictions of the

impact climate

change will have

on the

distribution of

mosquitoes

Determine the

knowledge,

perception, and

adaption

regarding dengue

fever in survey

responders

Vector

surveillance from

Mexico City over

five years

Analyzing how

climate change

will affect the

spread of Ae. 
aegypti into new

areas

Modelling the potential

distribution of

arbovirus vector Aedes

aegypti under current

2019

Liu

Modelling

and future climate

Asia

potential future

scenarios in Taiwan,

China

Global expansion and redistribution of Aedesborne virus

North

transmission risk with

Ryan

America

USA

climate change

Geographic shifts in

Aedes aegypti habitat

suitability in Ecuador

using larval surveillance

data and ecological

2019

Lippi

South

niche modeling

America

Ecuador

Modeling the

global

implications of climate

change for public health

vector control

Temperature impacts

on dengue emergence in

the United States:

investigating the role of

2019

Robert

North

seasonality and climate

change

The current and future global distribution and population at risk of

2019

Messina

Europe

United

dengue

America

USA

transmission risk

by two mosquito

vectors in current

climates and

comparing to

climate change

projections

Modelling the

current spatial

distribution of Ae.

aegypti and

projecting future

scenarios with

climate change

Modelling how

DTR fluctuations

could affect

potential dengue

suitability

Projecting how

climate change

may change

global

environments to

be more suitable

for dengue

A review on

The effect of global

change on mosquito-

2019

Franklinos

Europe

United

borne disease

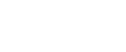

Kingdom

whether climate

change will

impact mosquito-

borne diseases

Estimating past,

present, and future

trends in the global

2019

Liu-

Helmersson
Modelling

estimated change in Ae. aegypti 
distribution and

abundance of the

arbovirus vector Aedes

aegypti under climate

change scenarios population and

distribution due

to climate change

Thermal biology of mosquito-borne disease

2019

Mordecai

North

America

USA

Reviewing how temperature dependence of vector transmission can be predicted using trait-based approaches Reviewing the impact of

Climatic conditions: conventional and nanotechnology-based methods for the control 2019 Ahmed Asia

Pakistan nanotechnologybased and of mosquito vectors causing human health issues

\section{Environmental} suitability for Aedes aegypti and Aedes albopictus and the spatial distribution of major arboviral infections in Mexico Co-developing climate services for public health: stakeholder needs and perceptions for the prevention and control of Aedestransmitted diseases in the Caribbean

Dengue incidence and sociodemographic conditions in Pucallpa, Peruvian Amazon: what role for modification of 2020 Lubinda

Central America Mexico Modelling of environmental suitability for two mosquito vectors approaches on malaria and dengue fever control

the dengue-temperature relationship?

Identify climatic and health

2019 Stewart-Ibarra Caribbean Multiple needs in regards to arboviruses

Assessing the sociodemographic effect of the denguetemperature relationship to identify potential heightened risk due to climate change 
The dengue epidemic and climate change in Nepal
Pandey

Asia

Nepal

Climate change, health and mosquito-borne diseases: trends and implications to the pacific region

Projecting the future of dengue under climate change scenarios: 2020 $\mathrm{Xu}$

Oceania Australia progress, uncertainties and research needs

Current and projected distributions of Aedes aegypti and Ae.

Khan

albopictus in Canada and the US

A spatial-temporal study for the spread of dengue depending on

climate factors in

Pakistan (2006-2017)
How climate change is affecting dengue infection spread by two mosquito vectors

How climate change will affect human health

Review what information is available on how climate change will affect dengue transmission

Modelling ecological niches for two mosquito vectors

Used geographical information system maps over several years to identify the intensity of the spread of dengue 
Supplementary panel 3: List of publications included in systematic map and analysis

1. Shope, R. (1991). Global climate change and infectious diseases. Environmental Health Perspectives, 96, 171-174. https://doi.org/10.1289/ehp.9196171

2. Stein, M., Oria, G. I., Almirón, W. R., \& Willener, J. A. (2005). [Seasonal fluctuation of Aedes aegypti in Chaco Province, Argentina]. Revista De Saude Publica, 39(4), 559-564. https://doi.org/10.1590/s0034-89102005000400007

3. Dengue virus-mosquito interactions-PubMed. (n.d.). Retrieved August 18, 2021, from https://pubmed.ncbi.nlm.nih.gov/17803458/

4. Yang, H. M., Macoris, M. L. G., Galvani, K. C., Andrighetti, M. T. M., \& Wanderley, D. M. V. (2009). Assessing the effects of temperature on the population of Aedes aegypti, the vector of dengue. Epidemiology and Infection, 137(8), 1188-1202.

https://doi.org/10.1017/S0950268809002040

5. Russell, R. C., Currie, B. J., Lindsay, M. D., Mackenzie, J. S., Ritchie, S. A., \& Whelan, P. I. (2009). Dengue and climate change in Australia: Predictions for the future should incorporate knowledge from the past. The Medical Journal of Australia, 190(5), 265-268. https://doi.org/10.5694/j.1326-5377.2009.tb02393.x

6. Beebe, N. W., Cooper, R. D., Mottram, P., \& Sweeney, A. W. (2009). Australia's dengue risk driven by human adaptation to climate change. PLoS Neglected Tropical Diseases, 3(5), e429. https://doi.org/10.1371/journal.pntd.0000429

7. Weaver, S. C., \& Reisen, W. K. (2010). Present and future arboviral threats. Antiviral Research, 85(2), 328-345. https://doi.org/10.1016/j.antiviral.2009.10.008

8. Hii, Y. L., Rocklöv, J., Ng, N., Tang, C. S., Pang, F. Y., \& Sauerborn, R. (2009). Climate variability and increase in intensity and magnitude of dengue incidence in Singapore. Global Health Action, 2. https://doi.org/10.3402/gha.v2i0.2036

9. Herrera-Martinez, A. D., \& Rodríguez-Morales, A. J. (2010). Potential influence of climate variability on dengue incidence registered in a western pediatric Hospital of Venezuela. Tropical Biomedicine, 27(2), 280-286.

10. Banu, S., Hu, W., Hurst, C., \& Tong, S. (2011). Dengue transmission in the Asia-Pacific region: Impact of climate change and socio-environmental factors. Tropical Medicine $\mathcal{E}$ International Health: TM \& IH, 16(5), 598-607. https://doi.org/10.1111/j.1365$\underline{3156.2011 .02734 . x}$

11. Mohammed, A., \& Chadee, D. D. (2011). Effects of different temperature regimens on the development of Aedes aegypti (L.) (Diptera: Culicidae) mosquitoes. Acta Tropica, 119(1), 38-43. https://doi.org/10.1016/j.actatropica.2011.04.004

12. Thai, K. T. D., \& Anders, K. L. (2011). The role of climate variability and change in the transmission dynamics and geographic distribution of dengue. Experimental Biology and Medicine (Maywood, N.J.), 236(8), 944-954. https://doi.org/10.1258/ebm.2011.010402

13. Farjana, T., Tuno, N., \& Higa, Y. (2012). Effects of temperature and diet on development and interspecies competition in Aedes aegypti and Aedes albopictus. Medical and Veterinary Entomology, 26(2), 210-217. https://doi.org/10.1111/j.1365- 
14. Descloux, E., Mangeas, M., Menkes, C. E., Lengaigne, M., Leroy, A., Tehei, T., Guillaumot, L., Teurlai, M., Gourinat, A.-C., Benzler, J., Pfannstiel, A., Grangeon, J.-P., Degallier, N., \& De Lamballerie, X. (2012). Climate-based models for understanding and forecasting dengue epidemics. PLoS Neglected Tropical Diseases, 6(2), e1470. https://doi.org/10.1371/journal.pntd.0001470

15. Ramasamy, R., \& Surendran, S. N. (2012). Global climate change and its potential impact on disease transmission by salinity-tolerant mosquito vectors in coastal zones. Frontiers in Physiology, 3, 198. https://doi.org/10.3389/fphys.2012.00198

16. Lozano-Fuentes, S., Hayden, M. H., Welsh-Rodriguez, C., Ochoa-Martinez, C., TapiaSantos, B., Kobylinski, K. C., Uejio, C. K., Zielinski-Gutierrez, E., Monache, L. D., Monaghan, A. J., Steinhoff, D. F., \& Eisen, L. (2012). The dengue virus mosquito vector Aedes aegypti at high elevation in Mexico. The American Journal of Tropical Medicine and Hygiene, 87(5), 902-909. https://doi.org/10.4269/ajtmh.2012.12-0244

17. Oki, M., \& Yamamoto, T. (2012). Climate change, population immunity, and hyperendemicity in the transmission threshold of dengue. PloS One, 7(10), e48258. https://doi.org/10.1371/journal.pone.0048258

18. Adelman, Z. N., Anderson, M. A. E., Wiley, M. R., Murreddu, M. G., Samuel, G. H., Morazzani, E. M., \& Myles, K. M. (2013). Cooler temperatures destabilize RNA interference and increase susceptibility of disease vector mosquitoes to viral infection. PLoS Neglected Tropical Diseases, 7(5), e2239. https://doi.org/10.1371/journal.pntd.0002239

19. Morin, C. W., Comrie, A. C., \& Ernst, K. (2013). Climate and dengue transmission: Evidence and implications. Environmental Health Perspectives, 121(11-12), 1264-1272. https://doi.org/10.1289/ehp.1306556

20. Colón-González, F. J., Fezzi, C., Lake, I. R., \& Hunter, P. R. (2013). The effects of weather and climate change on dengue. PLoS Neglected Tropical Diseases, 7(11), e2503. https://doi.org/10.1371/journal.pntd.0002503

21. Liu-Helmersson, J., Stenlund, H., Wilder-Smith, A., \& Rocklöv, J. (2014). Vectorial capacity of Aedes aegypti: Effects of temperature and implications for global dengue epidemic potential. PloS One, 9(3), e89783. https://doi.org/10.1371/journal.pone.0089783

22. Capinha, C., Rocha, J., \& Sousa, C. A. (2014). Macroclimate determines the global range limit of Aedes aegypti. EcoHealth, 11(3), 420-428. https://doi.org/10.1007/s10393-014$\underline{0918-\mathrm{y}}$

23. Naish, S., Dale, P., Mackenzie, J. S., McBride, J., Mengersen, K., \& Tong, S. (2014). Climate change and dengue: A critical and systematic review of quantitative modelling approaches. BMC Infectious Diseases, 14, 167. https://doi.org/10.1186/1471-2334-14-167

24. Khormi, H. M., \& Kumar, L. (2014). Climate change and the potential global distribution of Aedes aegypti: Spatial modelling using GIS and CLIMEX. Geospatial Health, 8(2), 405-415. https://doi.org/10.4081/gh.2014.29

25. Dhimal, M., Gautam, I., Kreß, A., Müller, R., \& Kuch, U. (2014). Spatio-temporal distribution of dengue and lymphatic filariasis vectors along an altitudinal transect in 
Central Nepal. PLoS Neglected Tropical Diseases, 8(7), e3035.

https://doi.org/10.1371/journal.pntd.0003035

26. Bouzid, M., Colón-González, F. J., Lung, T., Lake, I. R., \& Hunter, P. R. (2014). Climate change and the emergence of vector-borne diseases in Europe: Case study of dengue fever. BMC Public Health, 14, 781. https://doi.org/10.1186/1471-2458-14-781

27. Méndez-Lázaro, P., Muller-Karger, F. E., Otis, D., McCarthy, M. J., \& Peña-Orellana, M. (2014). Assessing climate variability effects on dengue incidence in San Juan, Puerto Rico. International Journal of Environmental Research and Public Health, 11(9), 9409-9428. https://doi.org/10.3390/ijerph110909409

28. Williams, C. R., Mincham, G., Ritchie, S. A., Viennet, E., \& Harley, D. (2014). Bionomic response of Aedes aegypti to two future climate change scenarios in far north Queensland, Australia: Implications for dengue outbreaks. Parasites \& Vectors, 7, 447. https://doi.org/10.1186/1756-3305-7-447

29. Rogers, D. J. (2015). Dengue: Recent past and future threats. Philosophical Transactions of the Royal Society of London. Series B, Biological Sciences, 370(1665), 20130562. https://doi.org/10.1098/rstb.2013.0562

30. Campbell, L. P., Luther, C., Moo-Llanes, D., Ramsey, J. M., Danis-Lozano, R., \& Peterson, A. T. (2015). Climate change influences on global distributions of dengue and chikungunya virus vectors. Philosophical Transactions of the Royal Society of London. Series B, Biological Sciences, 370(1665), 20140135. https://doi.org/10.1098/rstb.2014.0135

31. Dhimal, M., Gautam, I., Joshi, H. D., O’Hara, R. B., Ahrens, B., \& Kuch, U. (2015). Risk factors for the presence of chikungunya and dengue vectors (Aedes aegypti and Aedes albopictus), their altitudinal distribution and climatic determinants of their abundance in central Nepal. PLoS Neglected Tropical Diseases, 9(3), e0003545.

https://doi.org/10.1371/journal.pntd.0003545

32. Junxiong, P., \& Yee-Sin, L. (2015). Clustering, climate and dengue transmission. Expert Review of Anti-Infective Therapy, 13(6), 731-740.

https://doi.org/10.1586/14787210.2015.1028364

33. Ortiz, P. L., Rivero, A., Linares, Y., Pérez, A., \& Vázquez, J. R. (2015). Spatial Models for Prediction and Early Warning of Aedes aegypti Proliferation from Data on Climate Change and Variability in Cuba. MEDICC Review, 17(2), 20-28. https://doi.org/10.37757/MR2015.V17.N2.6

34. Dhimal, M., Ahrens, B., \& Kuch, U. (2015). Climate Change and Spatiotemporal Distributions of Vector-Borne Diseases in Nepal-A Systematic Synthesis of Literature. PloS One, 10(6), e0129869. https://doi.org/10.1371/journal.pone.0129869

35. Struchiner, C. J., Rocklöv, J., Wilder-Smith, A., \& Massad, E. (2015). Increasing Dengue Incidence in Singapore over the Past 40 Years: Population Growth, Climate and Mobility. PloS One, 10(8), e0136286. https://doi.org/10.1371/journal.pone.0136286

36. Teurlai, M., Menkès, C. E., Cavarero, V., Degallier, N., Descloux, E., Grangeon, J.-P., Guillaumot, L., Libourel, T., Lucio, P. S., Mathieu-Daudé, F., \& Mangeas, M. (2015). Socio-economic and Climate Factors Associated with Dengue Fever Spatial 
Heterogeneity: A Worked Example in New Caledonia. PLoS Neglected Tropical Diseases, 9(12), e0004211. https://doi.org/10.1371/journal.pntd.0004211

37. Ehelepola, N. D. B., \& Ariyaratne, K. (2015). The interrelationship between dengue incidence and diurnal ranges of temperature and humidity in a Sri Lankan city and its potential applications. Global Health Action, 8, 29359.

https://doi.org/10.3402/gha.v8.29359

38. Chadee, D. D., \& Martinez, R. (2016). Aedes aegypti (L.) in Latin American and Caribbean region: With growing evidence for vector adaptation to climate change? Acta Tropica, 156, 137-143. https://doi.org/10.1016/j.actatropica.2015.12.022

39. Misslin, R., Telle, O., Daudé, E., Vaguet, A., \& Paul, R. E. (2016). Urban climate versus global climate change-what makes the difference for dengue? Annals of the New York Academy of Sciences, 1382(1), 56-72. https://doi.org/10.1111/nyas.13084

40. Liu-Helmersson, J., Quam, M., Wilder-Smith, A., Stenlund, H., Ebi, K., Massad, E., \& Rocklöv, J. (2016). Climate Change and Aedes Vectors: 21st Century Projections for Dengue Transmission in Europe. EBioMedicine, 7, 267-277.

https://doi.org/10.1016/j.ebiom.2016.03.046

41. Williams, C. R., Mincham, G., Faddy, H., Viennet, E., Ritchie, S. A., \& Harley, D. (2016). Projections of increased and decreased dengue incidence under climate change. Epidemiology and Infection, 144(14), 3091-3100. https://doi.org/10.1017/S095026881600162X

42. Ebi, K. L., \& Nealon, J. (2016). Dengue in a changing climate. Environmental Research, 151, 115-123. https://doi.org/10.1016/j.envres.2016.07.026

43. Tabachnick, W. J. (2016). Climate Change and the Arboviruses: Lessons from the Evolution of the Dengue and Yellow Fever Viruses. Annual Review of Virology, 3(1), 125-145. https://doi.org/10.1146/annurev-virology-110615-035630

44. Ehelepola, N. D. B., \& Ariyaratne, K. (2016). The correlation between dengue incidence and diurnal ranges of temperature of Colombo district, Sri Lanka 2005-2014. Global Health Action, 9, 32267. https://doi.org/10.3402/gha.v9.32267

45. Mweya, C. N., Kimera, S. I., Stanley, G., Misinzo, G., \& Mboera, L. E. G. (2016). Climate Change Influences Potential Distribution of Infected Aedes aegypti Co-Occurrence with Dengue Epidemics Risk Areas in Tanzania. PloS One, 11(9), e0162649. https://doi.org/10.1371/journal.pone.0162649

46. Butterworth, M. K., Morin, C. W., \& Comrie, A. C. (2017). An Analysis of the Potential Impact of Climate Change on Dengue Transmission in the Southeastern United States. Environmental Health Perspectives, 125(4), 579-585. https://doi.org/10.1289/EHP218

47. Escobar, L. E., Romero-Alvarez, D., Leon, R., Lepe-Lopez, M. A., Craft, M. E., BorborCordova, M. J., \& Svenning, J.-C. (2016). Declining Prevalence of Disease Vectors Under Climate Change. Scientific Reports, 6, 39150. https://doi.org/10.1038/srep39150

48. Caminade, C., Turner, J., Metelmann, S., Hesson, J. C., Blagrove, M. S. C., Solomon, T., Morse, A. P., \& Baylis, M. (2017). Global risk model for vector-borne transmission of Zika virus reveals the role of El Niño 2015. Proceedings of the National Academy of 
Sciences of the United States of America, 114(1), 119-124.

https://doi.org/10.1073/pnas.1614303114

49. Akter, R., Hu, W., Naish, S., Banu, S., \& Tong, S. (2017). Joint effects of climate variability and socioecological factors on dengue transmission: Epidemiological evidence. Tropical Medicine \& International Health: TM E IH, 22(6), 656-669.

https://doi.org/10.1111/tmi.12868

50. Tjaden, N. B., Suk, J. E., Fischer, D., Thomas, S. M., Beierkuhnlein, C., \& Semenza, J. C. (2017). Modelling the effects of global climate change on Chikungunya transmission in the 21st century. Scientific Reports, 7(1), 3813. https://doi.org/10.1038/s41598-017-03566-3

51. Mutheneni, S. R., Morse, A. P., Caminade, C., \& Upadhyayula, S. M. (2017). Dengue burden in India: Recent trends and importance of climatic parameters. Emerging Microbes \& Infections, 6(8), e70. https://doi.org/10.1038/emi.2017.57

52. Ruiz, E. F., Vasquez-Galindo, C. M., Aquije-Pariona, X. M., \& Torres-Roman, J. S. (2018). Outbreaks caused by Aedes aegyptis due to El Niño in a coastal area of Peru. Travel Medicine and Infectious Disease, 21, 78-79.

https://doi.org/10.1016/j.tmaid.2017.11.003

53. Li, C., Lu, Y., Liu, J., \& Wu, X. (2018). Climate change and dengue fever transmission in China: Evidences and challenges. The Science of the Total Environment, 622-623, 493-501. https://doi.org/10.1016/j.scitotenv.2017.11.326

54. Acharya, B. K., Cao, C., Xu, M., Khanal, L., Naeem, S., \& Pandit, S. (2018). Present and Future of Dengue Fever in Nepal: Mapping Climatic Suitability by Ecological Niche Model. International Journal of Environmental Research and Public Health, 15(2), E187. https://doi.org/10.3390/ijerph15020187

55. Carneiro, M. A. F., Alves, B. da C. A., Gehrke, F. de S., Domingues, J. N., Sá, N., Paixão, S., Figueiredo, J., Ferreira, A., Almeida, C., Machi, A., Savóia, E., Nascimento, V., \& Fonseca, F. (2017). Environmental factors can influence dengue reported cases. Revista Da Associacao Medica Brasileira (1992), 63(11), 957-961. https://doi.org/10.1590/1806$\underline{9282.63 .11 .957}$

56. Monaghan, A. J., Sampson, K. M., Steinhoff, D. F., Ernst, K. C., Ebi, K. L., Jones, B., \& Hayden, M. H. (2018). The potential impacts of 21st century climatic and population changes on human exposure to the virus vector mosquito Aedes aegypti. Climatic Change, 146(3-4), 487-500. https://doi.org/10.1007/s10584-016-1679-0

57. Colón-González, F. J., Harris, I., Osborn, T. J., Steiner São Bernardo, C., Peres, C. A., Hunter, P. R., \& Lake, I. R. (2018). Limiting global-mean temperature increase to 1.5-2 ${ }^{\circ} \mathrm{C}$ could reduce the incidence and spatial spread of dengue fever in Latin America. Proceedings of the National Academy of Sciences of the United States of America, 115(24), 6243-6248. https://doi.org/10.1073/pnas.1718945115

58. Reinhold, J. M., Lazzari, C. R., \& Lahondère, C. (2018). Effects of the Environmental Temperature on Aedes aegypti and Aedes albopictus Mosquitoes: A Review. Insects, 9(4), E158. https://doi.org/10.3390/insects9040158 
59. Carbajo, A. E., Cardo, M. V., \& Vezzani, D. (2019). Past, present and future of Aedes aegypti in its South American southern distribution fringe: What do temperature and population tell us? Acta Tropica, 190, 149-156.

https://doi.org/10.1016/j.actatropica.2018.11.017

60. Kamal, M., Kenawy, M. A., Rady, M. H., Khaled, A. S., \& Samy, A. M. (2018). Mapping the global potential distributions of two arboviral vectors Aedes aegypti and Ae. Albopictus under changing climate. PloS One, 13(12), e0210122.

https://doi.org/10.1371/journal.pone.0210122

61. Liu, B., Gao, X., Ma, J., Jiao, Z., Xiao, J., Hayat, M. A., \& Wang, H. (2019). Modeling the present and future distribution of arbovirus vectors Aedes aegypti and Aedes albopictus under climate change scenarios in Mainland China. The Science of the Total Environment, 664, 203-214. https://doi.org/10.1016/j.scitotenv.2019.01.301

62. Bakhsh, K., Sana, F., \& Ahmad, N. (2018). Dengue fever in Punjab, Pakistan: Knowledge, perception and adaptation among urban adults. The Science of the Total Environment, 644, 1304-1311. https://doi.org/10.1016/j.scitotenv.2018.07.077

63. Dávalos-Becerril, E., Correa-Morales, F., González-Acosta, C., Santos-Luna, R., PeraltaRodríguez, J., Pérez-Rentería, C., Ordoñez-Álvarez, J., Huerta, H., Carmona-Perez, M., Díaz-Quiñonez, J. A., Mejía-Guevara, M. D., Sánchez-Tejeda, G., Kuri-Morales, P., González-Roldán, J. F., \& Moreno-García, M. (2019). Urban and semi-urban mosquitoes of Mexico City: A risk for endemic mosquito-borne disease transmission. PloS One, 14(3), e0212987. https://doi.org/10.1371/journal.pone.0212987

64. Liu-Helmersson, J., Rocklöv, J., Sewe, M., \& Brännström, Å. (2019). Climate change may enable Aedes aegypti infestation in major European cities by 2100. Environmental Research, 172, 693-699. https://doi.org/10.1016/j.envres.2019.02.026

65. Liu, B., Jiao, Z., Ma, J., Gao, X., Xiao, J., Hayat, M. A., \& Wang, H. (2019). Modelling the potential distribution of arbovirus vector Aedes aegypti under current and future climate scenarios in Taiwan, China. Pest Management Science, 75(11), 3076-3083.

https://doi.org/10.1002/ps.5424

66. Ryan, S. J., Carlson, C. J., Mordecai, E. A., \& Johnson, L. R. (2019). Global expansion and redistribution of Aedes-borne virus transmission risk with climate change. PLoS Neglected Tropical Diseases, 13(3), e0007213. https://doi.org/10.1371/journal.pntd.0007213

67. Lippi, C. A., Stewart-Ibarra, A. M., Loor, M. E. F. B., Zambrano, J. E. D., Lopez, N. A. E., Blackburn, J. K., \& Ryan, S. J. (2019). Geographic shifts in Aedes aegypti habitat suitability in Ecuador using larval surveillance data and ecological niche modeling: Implications of climate change for public health vector control. PLoS Neglected Tropical Diseases, 13(4), e0007322. https://doi.org/10.1371/journal.pntd.0007322

68. Robert, M. A., Christofferson, R. C., Weber, P. D., \& Wearing, H. J. (2019). Temperature impacts on dengue emergence in the United States: Investigating the role of seasonality and climate change. Epidemics, 28, 100344. https://doi.org/10.1016/j.epidem.2019.05.003

69. Messina, J. P., Brady, O. J., Golding, N., Kraemer, M. U. G., Wint, G. R. W., Ray, S. E., Pigott, D. M., Shearer, F. M., Johnson, K., Earl, L., Marczak, L. B., Shirude, S., Davis 
Weaver, N., Gilbert, M., Velayudhan, R., Jones, P., Jaenisch, T., Scott, T. W., Reiner, R. C., \& Hay, S. I. (2019). The current and future global distribution and population at risk of dengue. Nature Microbiology, 4(9), 1508-1515. https://doi.org/10.1038/s41564-019$\underline{0476-8}$

70. Franklinos, L. H. V., Jones, K. E., Redding, D. W., \& Abubakar, I. (2019). The effect of global change on mosquito-borne disease. The Lancet. Infectious Diseases, 19(9), e302e312. https://doi.org/10.1016/S1473-3099(19)30161-6

71. Liu-Helmersson, J., Brännström, Å., Sewe, M. O., Semenza, J. C., \& Rocklöv, J. (2019). Estimating Past, Present, and Future Trends in the Global Distribution and Abundance of the Arbovirus Vector Aedes aegypti Under Climate Change Scenarios. Frontiers in Public Health, 7, 148. https://doi.org/10.3389/fpubh.2019.00148

72. Mordecai, E. A., Caldwell, J. M., Grossman, M. K., Lippi, C. A., Johnson, L. R., Neira, M., Rohr, J. R., Ryan, S. J., Savage, V., Shocket, M. S., Sippy, R., Stewart Ibarra, A. M., Thomas, M. B., \& Villena, O. (2019). Thermal biology of mosquito-borne disease. Ecology Letters, 22(10), 1690-1708. https://doi.org/10.1111/ele.13335

73. Ahmed, T., Hyder, M. Z., Liaqat, I., \& Scholz, M. (2019). Climatic Conditions: Conventional and Nanotechnology-Based Methods for the Control of Mosquito Vectors Causing Human Health Issues. International Journal of Environmental Research and Public Health, 16(17), E3165. https://doi.org/10.3390/ijerph16173165

74. Lubinda, J., Treviño C, J. A., Walsh, M. R., Moore, A. J., Hanafi-Bojd, A. A., Akgun, S., Zhao, B., Barro, A. S., Begum, M. M., Jamal, H., Angulo-Molina, A., \& Haque, U. (2019). Environmental suitability for Aedes aegypti and Aedes albopictus and the spatial distribution of major arboviral infections in Mexico. Parasite Epidemiology and Control, 6, e00116. https://doi.org/10.1016/j.parepi.2019.e00116

75. Stewart-Ibarra, A. M., Romero, M., Hinds, A. Q. J., Lowe, R., Mahon, R., Van Meerbeeck, C. J., Rollock, L., Gittens-St Hilaire, M., St Ville, S., Ryan, S. J., Trotman, A. R., \& Borbor-Cordova, M. J. (2019). Co-developing climate services for public health: Stakeholder needs and perceptions for the prevention and control of Aedestransmitted diseases in the Caribbean. PLoS Neglected Tropical Diseases, 13(10), e0007772. https://doi.org/10.1371/journal.pntd.0007772

76. Charette, M., Berrang-Ford, L., Coomes, O., Llanos-Cuentas, E. A., Cárcamo, C., Kulkarni, M., \& Harper, S. L. (2020). Dengue Incidence and Sociodemographic Conditions in Pucallpa, Peruvian Amazon: What Role for Modification of the DengueTemperature Relationship? The American Journal of Tropical Medicine and Hygiene, 102(1), 180-190. https://doi.org/10.4269/ajtmh.19-0033

77. Pandey, B. D., \& Costello, A. (2019). The dengue epidemic and climate change in Nepal. Lancet (London, England), 394(10215), 2150-2151. https://doi.org/10.1016/S01406736(19)32689-3

78. Filho, W. L., Scheday, S., Boenecke, J., Gogoi, A., Maharaj, A., \& Korovou, S. (2019). Climate Change, Health and Mosquito-Borne Diseases: Trends and Implications to the 
Pacific Region. International Journal of Environmental Research and Public Health, 16(24), E5114. https://doi.org/10.3390/ijerph16245114

79. Xu, Z., Bambrick, H., Frentiu, F. D., Devine, G., Yakob, L., Williams, G., \& Hu, W. (2020). Projecting the future of dengue under climate change scenarios: Progress, uncertainties and research needs. PLoS Neglected Tropical Diseases, 14(3), e0008118. https://doi.org/10.1371/journal.pntd.0008118

80. Khan, S. U., Ogden, N. H., Fazil, A. A., Gachon, P. H., Dueymes, G. U., Greer, A. L., \& $\mathrm{Ng}, \mathrm{V}$. (2020). Current and Projected Distributions of Aedes aegypti and Ae.

Albopictus in Canada and the U.S. Environmental Health Perspectives, 128(5), 57007. https://doi.org/10.1289/EHP5899

81. Shabbir, W., Pilz, J., \& Naeem, A. (2020). A spatial-temporal study for the spread of dengue depending on climate factors in Pakistan (2006-2017). BMC Public Health, 20(1), 995. https://doi.org/10.1186/s12889-020-08846-8 